\title{
Chromogranin from normal human adrenal glands: purification by monoclonal antibody affinity chromatography and partial N-terminal amino acid sequence
}

\author{
Barry S. Wilson*, Sem H. Phan and Ricardo V. Lloyd \\ Department of Pathology, University of Michigan Medical School, Ann Arbor, Michigan 48109, U.S.A.
}

(Received 21 August 1985; revised manuscript received 15 October 1985; accepted for publication 21 October 1985)

\section{Summary}

A method is presented for the purification of human chromogranin from adrenal glands obtained at autopsy. The procedure involved homogenization of whole glands in aqueous buffer, salt precipitation, affinity chromatography using a highly specific monoclonal antibody (LK2H10) and reverse-phase high-pressure liquid chromatography. Chromogranin purified from autopsy adrenal glands revealed a high degree of polypeptide heterogeneity when analyzed by silver-stained SDS polyacrylamide gels. Greater than $90 \%$ of the protein was represented by a cluster of polypeptides with an $M_{\mathrm{r}}=70000$ (i.e. chromogranin A), while the remaining protein was highly disperse in molecular weight. That these various polypeptides were in fact chromogranin was shown by Western blotting using monoclonal antibody LK2H10. About $6 \mathrm{nmol}$ of chromogranin were obtained from $97 \mathrm{~g}$ of starting adrenals which was estimated to be a $25 \%$ yield and a 250 -fold enrichment from adrenal homogenates. Critical to achieving reasonable yields of this protein was the need for particular low $\mathrm{pH}$ buffers for resuspension of chromogranin after solvent removal steps. Chromogranin purified from human adrenal glands was similar in amino acid composition, and identical in the $\mathrm{N}$-terminal amino acid sequence ( 24 residues) to bovine chromogranin A. A secondary sequence representing $25 \%$ of the total protein and missing the first three residues of the $\mathrm{N}$-terminus suggested the possibility of $\mathrm{N}$-terminal processing of chromogranin in situ. The conservation of the $\mathrm{N}$-terminal amino acid

* Present address and address for reprint requests: Barry S. Wilson, Department of Cell Biology, Hybritech Inc., 11095 Torreyana Rd., San Diego, CA 92121, U.S.A. Tel.: 619-455-6700. 
sequence of human and bovine chromogranin contrasts with the strong sequence variability predicted by antisera cross-reactivity and suggests that the $\mathrm{N}$-terminus of chromogranin may be critical for its biological activity.

chromogranin; adrenal glands; monoclonal antibody affinity chromatography; amino acid sequence; human; purification

\section{Introduction}

Catecholamine containing storage granules of adrenal chromaffin cells contain various soluble proteins which are released with catecholamines following neural stimulation [1-4]. The released granule proteins were originally referred to as the chromogranins based on their origin from adrenal chromaffin granules [4]. However, since distinct proteins such as dopamine beta-hydroxylase and the opioid family peptides have been identified in the soluble granule fraction (for review see Ref. 5), the term chromogranin most appropriately describes a complex family of polypeptides representing the majority of proteins of the soluble granule fraction. The chromogranins have a unique amino acid composition, being rich in acidic residues and in proline, and they also have an acidic $\mathrm{p} I$ (for review, see Ref. 5). In addition, they vary in their extent of glycosylation [6]. The most abundant of the chromogranins, termed chromogranin A, has a molecular size $\left(M_{\mathrm{r}}\right)$ of about 70000 and represents more than $40 \%$ of all the soluble granule protein (for review see Ref. 5). In addition to chromogranin A, numerous smaller size (between $M_{\mathrm{r}} 70000$ and 20000 ) as well as some larger size chromogranin polypeptides $\left(M_{\mathrm{r}} 85000\right.$ and $\left.>100000\right)$ have been identified by immunological cross-reactivity [7-10] and biochemical similarity $[6,11,12]$. Although the exact relationship between these various size chromogranin polypeptides is presently unclear, recent data implicates both gene duplication [12] and intragranular proteolytic processing $[9,12,13]$ in the generation of polypeptide heterogeneity.

The function of chromogranin in hormone storage granules is presently unknown. A number of studies utilizing bovine adrenal chromaffin vesicles have indicated that chromogranin may help to stabilize granule osmotic pressure by interacting with catecholamine and nucleotides [14-18]. However, this hypothesis has not been generally accepted because a direct relationship between amine storage and chromogranin presence is lacking $[11,19]$. Recent work by our laboratory and others has shown that chromogranin can be detected in a wide variety of polypeptide hormone producing cells $[8,10-13,20-23]$ and in neural tissue [11,19]. Thus, any function proposed for chromogranin must account for its widespread distribution as a neuroendocrine marker.

Our laboratory has been involved in the immunohistochemical detection of human chromogranin using a monoclonal antibody, LK2H10, produced in mice $[8,10]$. We have used LK2H10 to detect human chromogranin $[8,10,24,25]$ within secretory granules of most APUD type neuroendocrine cells [26] and their associated neoplasms. In this paper, we describe the use of $\mathrm{LK} 2 \mathrm{H} 10$ as part of a purification procedure for 
generating significant quantities of human chromogranin of high purity from a generally available source (i.e., autopsy adrenal glands). Using such material we have extended the $\mathrm{N}$-terminal sequence of chromogranin out to 28 residues and have identified evidence suggesting $\mathrm{N}$-terminal processing.

\section{Materials and Methods}

\section{Monoclonal antibody ( $\mathrm{LK2H10)}$ to human chromogranin}

The mouse IgG1 monoclonal antibody LK2H10 is secreted by a hybridoma formed by fusion of NS-1 myeloma cells with splenocytes from a mouse immunized with a human pheochromocytoma tumor. Details on the production of this antibody and its specificity for human chromogranins have been described previously [8,10]. Monoclonal antibody containing culture fluid was harvested from late log phase cells and used for Western blotting studies. Ascites fluids containing antibody LK2H10 were obtained by injection of $5 \times 10^{6}$ hybridoma cells i.p. in Balb/c mice primed previously with $0.5 \mathrm{ml}$ pristane. Purified LK2H10 was obtained from ascites fluids by a two step procedure employing salt precipitation and ion-exchange chromatography. Briefly, ascitic fluid was precipitated with 1 volume of saturated ammonium sulfate, adjusted to $\mathrm{pH} 7$ as described by Fahey [27]. The precipitated IgG was dialyzed against $0.005 \mathrm{M}$ phosphate buffer, $\mathrm{pH} 7.4$, and applied to a DEAE-Sepharose column equilibrated with the same buffer. The column was eluted by a salt gradient from

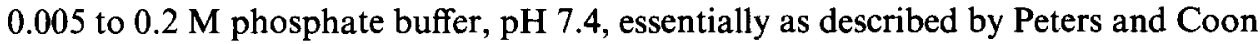
[28]. A small aliquot from each fraction was tested for IgG heavy and light chain purity by electrophoresis in a discontinuous polyacrylamide gel stained with Commassie Blue R250 (details below). Only those fractions containing highly purified antibody were pooled and used.

\section{Gel electrophoresis and silver staining}

Proteins were electrophoresed in $10 \times 8 \times 0.075 \mathrm{~cm}$ slab gels containing $10 \%$ cross-linked polyacrylamide (37:1, monomer to linker) and the discontinuous sodium dodecyl sulfate (SDS) buffer system of Laemmli [29]. Samples were heated to $100^{\circ} \mathrm{C}$ in SDS-sample buffer containing 2\% 2-mercaptoethanol and electrophoresis was performed at $14 \mathrm{~mA} / \mathrm{gel}$. Molecular weight standards were phosphorylase B (92000), bovine serum albumin (67000), ovalbumin (43000), carbonic anhydrase (29 000) and trypsin inhibitor $(21000)$.

For silver staining, gels were treated at room temperature in crystallizing dishes with gentle agitation as follows: (1) fixation in 50\% methanol/10\% acetic acid for 30 min, (2) $5 \%$ methanol $/ 7 \%$ acetic acid for $30 \mathrm{~min}$, (3) $10 \%$ glutaraldehyde for $1 \mathrm{~h}$, (4) wash with deionized $\mathrm{H}_{2} \mathrm{O}$ for $1 \mathrm{~h}$ (four changes), (5) dithiothreitol $\left(5 \mu \mathrm{g} / \mathrm{ml}\right.$ ) in $\mathrm{H}_{2} \mathrm{O}$ for $30 \mathrm{~min}$, (6) silver nitrate (Sigma) $0.1 \% \mathrm{w} / \mathrm{v}$ for $30 \mathrm{~min}$, (7) rinse with $50 \mathrm{ml} \mathrm{H}_{2} \mathrm{O}$, then twice with developer ( $50 \mu 137 \%$ formaldehyde in $100 \mathrm{ml} \mathrm{3 \%}$ sodium carbonate), (8) reaction is stopped with $2 \mathrm{M}$ citric acid. 


\section{Western blotting}

Protein from SDS gels was transferred to $0.45 \mu \mathrm{m}$ nitrocellulose paper (Millipore) by electrophoretic transfer using a Bio-Rad Transblotting Cell (Bio-Rad, Richmond, $\mathrm{CA})$. The transfer buffer and electrophoretic conditions ( $60 \mathrm{~V}$ for $4 \mathrm{~h}$ ) were as described by Towbin et al. [30]. After electrophoresis the paper was gently rotated at room temperature in glass crystallizing dishes with the following solutions: (1) $2 \%$ bovine serum albumin in $10 \mathrm{mM}$ phosphate $\mathrm{pH} 7.4$ and $0.85 \% \mathrm{NaCl}$ (PBS) for 30 min (to block non-specific binding), (2) 3 washes in PBS for $5 \mathrm{~min}$ each, (3) spent culture media containing monoclonal antibodies (about $10 \mu \mathrm{g} / \mathrm{ml}$ antibody) for $1 \mathrm{~h}$, (4) 3 washes in PBS for 5 min each, (5) peroxidase conjugated goat anti-mouse IgG (1/400 dilution in fetal calf serum in PBS) for $60 \mathrm{~min}$, (6) 3 washes in PBS for $5 \mathrm{~min}$ each, (7) color development in $5^{\prime}, 5^{\prime}$-diaminobenzidine $(1 \mathrm{mg} / \mathrm{ml}$ in PBS) containing $\mathrm{H}_{2} \mathrm{O}_{2}(0.02 \%)$.

\section{Protein dot blotting}

Detection of chromogranin was assessed by dot blotting in a Schleicher and Schüll Minifold 96-well apparatus (Keene, NJ). Nitrocellulose paper $(0.45 \mu \mathrm{M})$ pre-soaked in the transfer buffer of Towbin et al. [30] was clamped in the apparatus and the following solutions were added for $1.5 \mathrm{~min}$ and removed by vacuum: (1) $50 \mu \mathrm{l}$ of a chromogranin containing solution, (2) wash twice in PBS (100 $\mu$ l), (3) $100 \mu \mathrm{l}$ of $0.1 \%$ bovine serum albumin in PBS (previously heated to $100^{\circ} \mathrm{C}$ for $5 \mathrm{~min}$ ), (4) wash twice in PBS (100 $\mu$ l), (5) $75 \mu \mathrm{l} \mathrm{LK2H10} \mathrm{antibody} \mathrm{(spent} \mathrm{culture} \mathrm{media} \mathrm{containing} \mathrm{about}$ $10 \mu \mathrm{g} / \mathrm{ml}$ antibody), (6) wash 3 times with PBS $(100 \mu \mathrm{l})$. The paper was removed from the apparatus and then placed in a crystallizing dish and gently rotated with the following reagents at room temperature: (1) $10 \mathrm{~min}$ with $0.1 \%$ bovine serum albumin $\left(100^{\circ} \mathrm{C}\right.$ pretreated), (2) wash twice in PBS, (3) $30 \mathrm{~min}$ in peroxidase conjugated goat anti-mouse IgG (1/400 in 10\% fetal calf serum, PBS), (4) wash 3 times with PBS, (5) develop color with $5^{\prime}, 5^{\prime}$-diaminobenzidine ( $1 \mathrm{mg} / \mathrm{ml} \mathrm{PBS}$ ) containing $\mathrm{H}_{2} \mathrm{O}_{2}(0.02 \%)$. The latter series of steps was performed in the dish rather than in the dot blot apparatus, since lower background staining was achieved by this modification.

\section{Tissue processing}

Autopsy adrenal glands in patients without disease affecting the adrenal medulla were obtained at 8-24 h postmortem and kept at $-20^{\circ} \mathrm{C}$ until used. Glands were trimmed of excess fat, minced and extracted in 10 volumes of ice-cold PBS in a Waring blender. Proteolytic inhibitors added to the extraction buffer included phenylmethylsulfonyl fluoride $(1 \mathrm{mM})$, benzamidine $(10 \mathrm{mM}), N$-ethylmaleimide $(5 \mathrm{mM})$ and ethylenediaminetetraacetic acid $(5 \mathrm{mM})$. The extract was cleared by centrifugation at $27000 \times g$ at $4^{\circ} \mathrm{C}$. Congealed fat which floated to the top of the tube was removed by passing the supernatant through gauze. The extract was stored at $-20^{\circ} \mathrm{C}$; after thawing, additional insoluble material was removed by centrifugation as above. The crude adrenal extract was subjected to $\left(\mathrm{NH}_{4}\right)_{2} \mathrm{SO}_{4}$ precipitation at $55 \%$ saturation at room temperature. The precipitate was spun at $15^{\circ} \mathrm{C}$ for $10 \mathrm{~min}$ at a speed of $27000 \times g$ and the pellet suspended in 1/10 original volume in PBS. After several hours dialysis against PBS, the semi-crude chromogranin preparation was applied to an LK2H10 antibody affinity column (see below). 


\section{Antibody affinity chromatography}

Purified antibody LK2H10 was coupled to Sepharose CL4B beads (Pharmacia) at a concentration of $8 \mathrm{mg}$ protein/ $\mathrm{ml}$ of gel using the cyanogen bromide method [31]. Freshly activated gel was coupled by gently rotating overnight at $4^{\circ} \mathrm{C}$ with LK2H10 in $0.1 \mathrm{M} \mathrm{NaHCO}$, $\mathrm{pH}$ 9.0. Coupling at $\mathrm{pH} 6.5$ as described by Cuatrecasas [31] for reducing IgG denaturation was no more effective for affinity chromatography than $\mathrm{pH} 9.0$ coupling. Any uncoupled $\mathrm{CNBr}$ active sites were blocked by incubating the gel for $3 \mathrm{~h}$ with $0.1 \mathrm{M}$ glycine $\mathrm{pH} 8.4 .5 \mathrm{ml}$ of $\mathrm{LK} 2 \mathrm{H} 10$ gel was packed into a $1 \times$ $20 \mathrm{~cm}$ glass column (Pharmacia) and all buffers were run at a flow rate of $30 \mathrm{ml} / \mathrm{h}$. The column was utilized and stored at $4^{\circ} \mathrm{C}$. The semi-crude chromogranin fraction obtained after $\left(\mathrm{NH}_{4}\right)_{2} \mathrm{SO}_{4}$ precipitation (see previous section) was applied to the column, and the column washed with PBS until the absorbance $280 \mathrm{~nm}$ was $<0.01$. The column was then flushed with deionized $\mathrm{H}_{2} \mathrm{O}$ (conductivity $=1 \mu \mathrm{S}$ ) to remove salts, and the bound chromogranin was eluted with $0.5 \mathrm{~N} \mathrm{NH}_{4} \mathrm{OH}$. $50-\mu 1$ samples from the resulting 2-ml fractions were analyzed for chromogranin content by dot blotting. Samples containing chromogranin were pooled and dried in a Speed Vac (Savant Instruments, Westbury, NY).

\section{High-pressure liquid chromatography (HPLC)}

HPLC separation was undertaken using a Varian model 5560 system in conjunction with a Vista 402 data system. Separation at $30^{\circ} \mathrm{C}$ was by a reverse-phase (Supelco LC318) $30 \mathrm{~nm}$ diameter pore C18 column. After the affinity chromatography step, chromogranin was dried and then resuspended with $2 \mathrm{~N}$ acetic acid. $500 \mu \mathrm{l}$ samples were injected into the HPLC column. The flow rate was $0.8 \mathrm{ml} / \mathrm{min}$, and elution was accomplished by a 60 -min linear gradient of water to $40 \% n$-propanol, both containing $0.1 \%$ trifluoroacetic acid. $0.8-\mathrm{ml}$ fractions were collected and detection was performed at $280 \mathrm{~nm}$. Samples were dried using a Speed Vac concentrator (Savant Instruments) and resuspended in appropriate buffer for further assays.

\section{Amino acid sequences and composition}

Human chromogranin (about $3 \mathrm{nmol}$ ) was sequenced on an Applied Biosystems $470 \mathrm{~A}$ gas phase sequencer as originally described [32]. The phenyl-thiohydantoin amino acids were separated and identified by reverse-phase HPLC on an Ultrasphere ODS column using a step gradient of $25-50 \% \mathrm{CH}_{3} \mathrm{CN}$ containing $88 \mathrm{mM}$ $\mathrm{NH}_{4} \mathrm{CH}_{3} \mathrm{COO}, \mathrm{pH} 4.9$ throughout. The column was eluted at $50^{\circ} \mathrm{C}$ with a flow rate of $1 \mathrm{ml} / \mathrm{min}$.

Samples for amino acid composition were dried and treated overnight with $\mathrm{HCl}$ vapor to hydrolyze the protein. The amino acid analysis utilized the same HPLC column and conditions described above.

\section{Experimental Results}

\section{Stability of chromogranin from autopsy adrenal glands}

The value of autopsy glands as a source of chromogranin would depend on the 
ability of chromogranin to be stable in situ for reasonable periods of time after death (e.g. $24 \mathrm{~h}$ ) and to maintain stability under storage at $-20^{\circ} \mathrm{C}$. To directly assess this issue, a $4 \mathrm{~h}$ postmortem adrenal gland was obtained and frozen at $-20^{\circ} \mathrm{C}$ for one week. After thawing, the gland was minced thoroughly with a razor blade and divided into four equal aliquots for processing into soluble homogenates (see details in Methods). One aliquot was homogenized immediately and the others were stored in a humidified container at $4^{\circ} \mathrm{C}$ and processed 4,8 and $24 \mathrm{~h}$ later. As seen in Fig. 1, quantitation of chromogranin by dot blotting showed similar endpoint titer (1/128) indicating that equal amounts of chromogranin were present in all the homogenates. Western blotting of these homogenates also showed identical content of the large and abundant chromogranin species for all homogenates (Fig. 1). The Western blotting results were very similar among autopsy adrenal glands and were essentially the same as those from surgically excised tumor specimens frozen within 10 min after excision. The data indicate that chromogranin polypeptides in situ in autopsy glands are not routinely subjected to postmortem proteolysis during freeze thawing or maintenance at $4^{\circ} \mathrm{C}$.

\section{Purification of chromogranin}

Chromogranin was purified from adrenal glands by a four step procedure involving homogenization in neutral $\mathrm{pH}$ aqueous buffer, precipitation with $\left(\mathrm{NH}_{4}\right)_{2} \mathrm{SO}_{4}$ at $55 \%$ of saturation, antibody LK2H10 affinity chromatography and reverse-phase HPLC. $\left(\mathrm{NH}_{4}\right)_{2} \mathrm{SO}_{4}$ precipitation at saturation percentages of $40,50,60,70$ and $80 \%$ were initially tested and $50 \%$ was the lowest value that precipitated the majority of chromogranin. Although the salt precipitation step only results in a minimal enrichment of chromogranin (1-2-fold), it helps more by eliminating material that would get

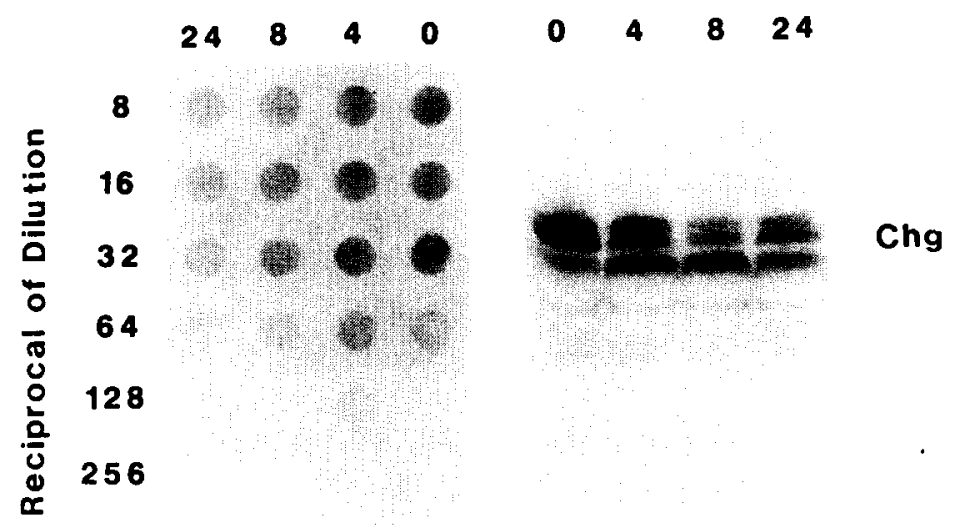

512

Fig. 1. Dot blot and Western blotting of chromogranin from an autopsy adrenal gland stored at $4^{\circ} \mathrm{C}$ for various hours. A 4-h post-mortem gland was minced and separated into four equal amounts. At the times indicated the sample was extracted and the amount of chromogranin was assessed by dot blotting (left hand panel). Western blot in the right hand panel shows that no breakdown occurred of the large main chromogranin polypeptides (labeled $\mathrm{Chg}$ ) during the $4^{\circ} \mathrm{C}$ incubation. Hours of incubation $(0,4,8,24)$ are listed on top of each figure. 
trapped in the antibody affinity column used in the next purification step. In this case, when acid or base is added, the trapped material gets eluted from the column and contaminates the purified chromogranin preparation.

The most significant step in the purification process was antibody affinity chromatography in which the salt cut preparations from two sets of adrenal glands were resuspended in a volume of approximately $20 \mathrm{ml}$ and this was passed once over a 5-ml antibody affinity column. Virtually all available chromogranin was bound to the column in a single passage. It was also critical to keep the column volume small since preliminary experiments utilizing a column size of about $50 \mathrm{ml}$ resulted in a high level of non-specific protein binding which could not be removed by the subsequent HPLC step.

After antibody affinity chromatography, an additional step involving reverse-phase HPLC was utilized in order to provide highly purified chromogranin for analytical studies such as amino acid sequencing. From preliminary studies using $n$-propanol, 2-propanol, $\mathrm{CH}_{3} \mathrm{CN}$ and both $\mathrm{C} 8$ and $\mathrm{C} 18$ columns, the most efficient separation of chromogranin with the best yield was achieved using a $\mathrm{C} 18$ column with a gradient of 0-40\% n-propanol. Chromogranin eluted as a single peak at about $30 \% n$-propanol (Fig. 2). Contaminant material absorbing at $280 \mathrm{~nm}$ is usually seen eluting both before and after the chromogranin peak (Fig. 2). The main fractions from the chromogranin HPLC peak were analyzed by silver staining and Western blotting in order to assess their polypeptide composition and their reactivity with LK2H10 antibody. As seen in Fig. 3, the main chromogranin fractions (43-50) contain major polypeptides of about $M_{\mathrm{r}} 70000$ with some $M_{\mathrm{r}}>100000$ and many polypeptides visible between $M_{\mathrm{r}} 43000$ and 28000 in size. The Western blot (Fig. 3, bottom) of these same fractions clearly shows that all these various polypeptides are in fact members of the chromogranin family since essentially all carry the antigenic determinant detected by LK2H10 antibody. The HPLC fractions $43-50$ were pooled from separate runs and were then used for amino acid composition and N-terminal sequencing. The HPLC fractions 51-55 were not used because of the presence of contaminating polypeptides, particularly in fractions 52 and 53, which were not detected by Western blotting with LK2H10 antibody (Fig. 3). About $6 \mathrm{nmol}$ of chromogranin were isolated from $97 \mathrm{~g}$ of whole human adrenal. A summary profile exhibiting the

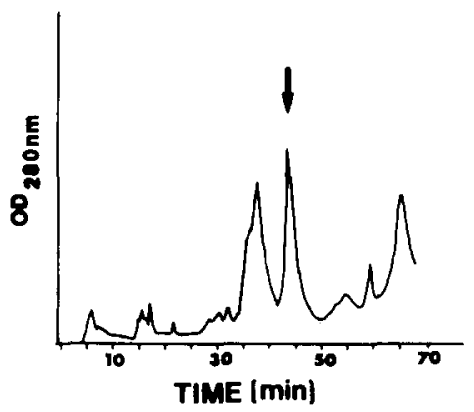

Fig. 2. HPLC chromatogram showing the location (arrow) of the chromogranin peak eluting at about $30 \%$-propanol. The material injected was previously purified on the monoclonal antibody LK2H10 affinity column. 


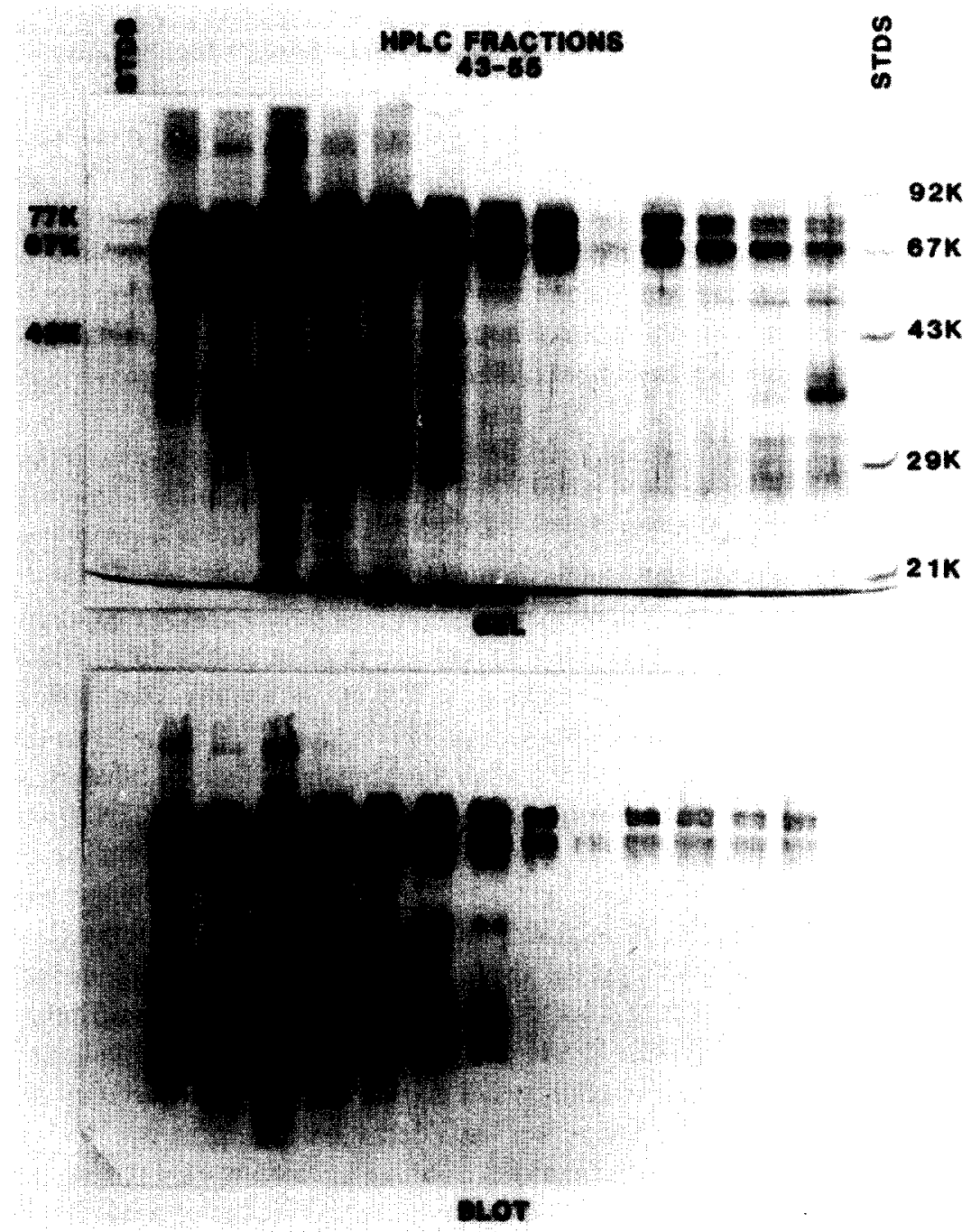

Fig. 3. Analysis of the purity of chromogranin detected after C18 HPLC separation. For the purpose 200 $\mu 1$ of each HPLC fraction (43-55 min) were used for the silver-stained gel and $100 \mu$ l of each HPLC fraction were used for the Western blot. Samples were dried in a Speed Vac and resuspended in $20 \mu 1$ SDS-sample buffer prior to SDS-gel electrophoresis. Fraction 45 in the silver-stained gel is estimated to contain about $60 \mu \mathrm{g}$ of protein based on our experiment with other samples.

protein polypeptide complexity at each step in the purification process from crude adrenal homogenate to the HPLC step is shown in Fig. 4. Lane 4 of Fig. 5 shows the polypeptide complexity of HPLC purified chromogranin. As expected, a heterogeneous molecular weight profile is seen and all bands visible are reactive with antibody LK2H10 (see Fig. 3). Densitometric scanning of lane 4 showed that the $M_{\mathrm{r}} 67000$ chromogranin polypeptide (chromogranin A) represented about $85 \%$ of the total chromogranin polypeptides isolated. As can be seen, the greatest purification occurred at the antibody affinity chromatography step with additional purification 


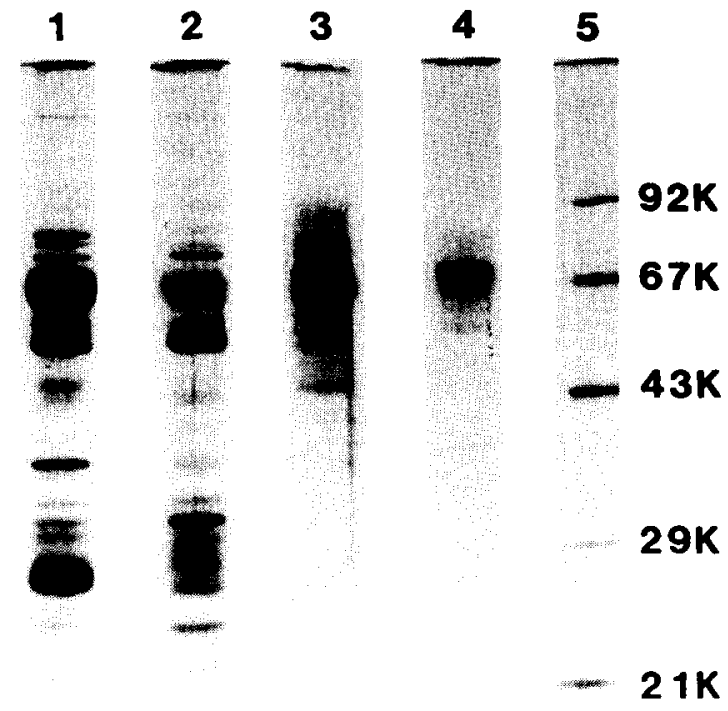

Fig. 4. SDS-gel electrophoresis and silver staining of proteins present during the successive steps in the purification of human chromogranin. Lane 1 contains $20 \mu \mathrm{g}$ of whole adrenal gland extract, lane 2 contains $10 \mu \mathrm{g}$ of the $50 \%\left(\mathrm{NH}_{4}\right)_{2} \mathrm{SO}_{4}$ precipitation, lane 3 contains $5 \mu \mathrm{g}$ of chromogranin purified by LK2H10 affinity chromatography, lane 4 contains $1 \mu \mathrm{g}$ of HPLC purified chromogranin (pool of fractions 43-50) and lane 5 contains molecular weight standards.

achieved by HPLC. From parallel experiments, the yield of chromogranin was monitored by assessing end point titers in dot blotting and by measuring protein concentration with the Bio-Rad protein assay. After all purification steps, the yield of chromogranin was estimated at $25 \%$ and a purification of 250 -fold.

First wash Second wash (pH 2.3)

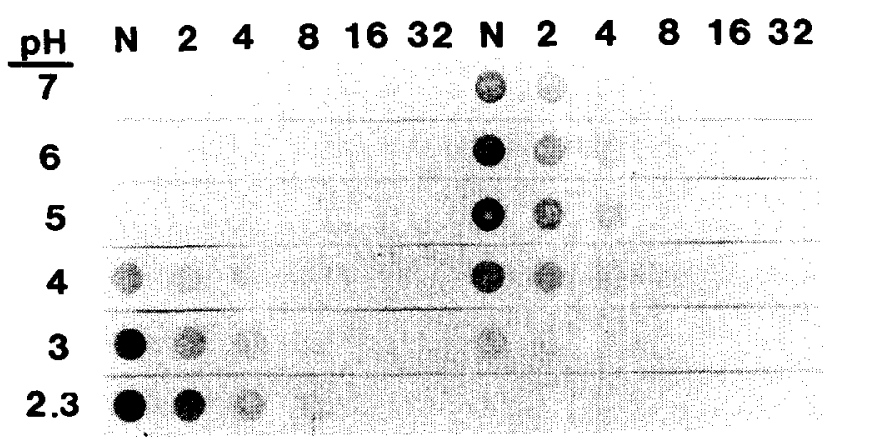

Fig. 5. Dot-blot analysis of chromogranin dried at $\mathrm{pH} 2.3$ and solubilized with buffers ranging in $\mathrm{pH}$ from 2.3 to 7 . The dried chromogranin was first treated with $2 \mathrm{~N} \mathrm{CH}_{3} \mathrm{COOH}$ or $0.5 \mathrm{~N} \mathrm{CH}_{3} \mathrm{COOH}(\mathrm{pH}$ 3) and acetate buffers whose $\mathrm{pH}$ is listed at the left column. The procedure involved vortexing for $1 \mathrm{~min}$ at room temperature. The tubes were then rinsed and any remaining insoluble chromogranin was solubilized as above by pH 2.3 ( $2 \mathrm{~N}$ acetic acid). Samples either undiluted $(\mathrm{N})$ or diluted as indicated at the top of the figure were dot blotted for detection of chromogranin by monoclonal antibody LK2H10. 


\section{Solubility requirements for purified chromogranin}

It was noted during the purification process that in several steps where liquid was removed by vacuum drying, chromogranin could not be readily resuspended in soluble form using $\mathrm{H}_{2} \mathrm{O}$ with or without neutral $\mathrm{pH}$ buffer. Because of the importance in maintaining good recovery of chromogranin at each step of purification, the effects of $\mathrm{pH}$ on chromogranin solubility were investigated. Fig. 5 illustrates the solubility of chromogranin eluted from an LK2H10 affinity column at pH 2.3 and then dried in equal aliquots. The aliquots were first suspended in various $\mathrm{pH}$ buffers, and any insoluble material was then suspended with $2 \mathrm{~N}$ acetic acid ( $\mathrm{pH}$ 2.3). The dot blotting analysis in Fig. 5 shows that chromogranin was not efficiently solubilized until buffers approaching $\mathrm{pH} 2$ were used. These data, together with additional experiments, are summarized in Table I. The solubility of chromogranin in neutral $\mathrm{pH}$ buffer was markedly reduced if drying was performed at low $\mathrm{pH}$ but not at high $\mathrm{pH}$ conditions (expt. A, Table I). Chromogranin dried at low $\mathrm{pH}$, although relatively insoluble at neutral $\mathrm{pH}$, was readily solubilized with either low or high $\mathrm{pH}$ conditions (expt. B, Table I). This phenomenon was observed whether drying occurred in glass or in polypropylene tubes. This requirement of $\mathrm{pH}$ extremes for efficient solubilization of acidified chromogranin was also observed using chromogranin eluted from the reverse-phase HPLC column which contains $n$-propanol and $0.1 \%$ trifluoroacetic acid (about $\mathrm{pH}$ 1.8). However, the $\mathrm{pH}$ is not the only condition required for efficient solubilization of chromogranin since $0.1 \%$ trifluoroacetic acid $(\mathrm{pH} 1.8)$ and $1 \mathrm{~N} \mathrm{HCl}$ $(\mathrm{pH}<1)$ were not as effective as were $2 \mathrm{~N}$ acetic acid $(\mathrm{pH} 2.3)$ or $80 \%$ formic acid $(\mathrm{pH}<1)$.

\section{TABLE I}

Effects of $\mathrm{pH}$ on the solubility of human adrenal chromogranin

\begin{tabular}{|c|c|c|c|c|c|}
\hline \multicolumn{3}{|l|}{ Expt. A } & \multicolumn{3}{|l|}{ Expt. B } \\
\hline $\begin{array}{l}\text { Drying }^{\mathbf{a}} \\
\mathrm{pH}\end{array}$ & $\begin{array}{l}\text { Suspending } \\
\mathrm{pH}\end{array}$ & Solubility $^{\mathrm{b}}$ & $\begin{array}{l}\text { Drying } \\
\text { pH }\end{array}$ & $\begin{array}{l}\text { Suspending } \\
\text { pH }\end{array}$ & Solubility $^{\mathbf{b}}$ \\
\hline 2.3 & 7 & - & 2.3 & 2.3 & ++++ \\
\hline 3 & 7 & + & 2.3 & 3 & +++ \\
\hline 4 & 7 & ++ & 2.3 & 4 & + \\
\hline 5 & 7 & +++ & 2.3 & 5 & - \\
\hline 6 & 7 & ++++ & 2.3 & 6 & - \\
\hline 7 & 7 & ++++ & 2.3 & 7 & - \\
\hline 8 & 7 & ++++ & 2.3 & 8 & + \\
\hline 9 & 7 & ++++ & 2.3 & 9 & ++ \\
\hline 10 & 7 & ++++ & 2.3 & 10 & +++ \\
\hline 11 & 7 & ++++ & 2.3 & 11 & ++++ \\
\hline
\end{tabular}

\footnotetext{
a All samples were dried under evaporation. The $\mathrm{pH} 2.3$ and 3.0 were achieved using $2 \mathrm{~N}$ and $0.5 \mathrm{~N}$ acid, respectively. The composition of buffers $\mathrm{pH} 4-7$ were $0.1 \mathrm{M}$ acetate, $\mathrm{pH} 8$ and 9 were $0.1 \mathrm{M}$ Tris, and $\mathrm{pH} 10$ and 11 were $0.1 \mathrm{M}$ carbonate.

b $\mathrm{A}++++$ reaction was equivalent to $100 \%$ solubility assayed by performing end-point titer in a dot blotting assay with monoclonal antibody LK2H10. Conditions for solubilization involved vortexing for $1 \mathrm{~min}$ at room temperature.
} 
An experiment was performed to determine if the above described solubility properties of chromogranin were typical of other adrenal homogenate proteins. For this purpose, whole adrenal homogenate diluted in $2 \mathrm{~N}$ acetic acid (pH 2.3) or neutral $\mathrm{pH}$ buffer was dried and those proteins not soluble at neutral $\mathrm{pH}$ were analyzed by SDS gel electrophoresis (Fig. 6). The experiment shows that essentially all detectable proteins dried under acid conditions were not solubilized at neutral $\mathrm{pH}$, indicating that this property was not unique to chromogranin. The above described $\mathrm{pH}$ effects on the solubility were also observed for human serum IgG but not for the serum protein albumin (data not shown).

\section{Biochemical analysis of human chromogranin}

Human autopsy adrenal chromogranin, purified by salt precipitation, antibody affinity chromatography and reverse-phase HPLC (fractions 43-50) was subjected to analysis by amino acid composition and $\mathrm{N}$-terminal amino acid sequence. As seen in Table II, the amino acid composition of human chromogranin is typical of this protein, being rich in acidic type residues (Asx and Glx), particularly Glx and having very low levels of Cys.

\section{TABLE II}

Amino acid composition of bovine chromogranin $\mathrm{A}$ and human chromogranin

\begin{tabular}{|c|c|c|c|c|}
\hline & \multicolumn{2}{|l|}{ mol/100 residues } & \multicolumn{2}{|l|}{ Residues/mol ${ }^{\mathrm{d}}$} \\
\hline & $\begin{array}{l}\text { Bovine } \\
\text { chromogranin } \mathrm{A}^{\mathrm{a}}\end{array}$ & $\begin{array}{l}\text { Human } \\
\text { chromogranin }^{\mathrm{b}}\end{array}$ & $\begin{array}{l}\text { Bovine } \\
\text { chromogranin } A^{c}\end{array}$ & $\begin{array}{l}\text { Human } \\
\text { chromogranin }\end{array}$ \\
\hline Asx & 8.0 & 7.2 & 44 & 47 \\
\hline Glx & 22.5 & 22.9 & 144 & 149 \\
\hline Ser & 7.7 & 10.0 & 47 & 65 \\
\hline Thr & 2.6 & 2.8 & 13 & 18 \\
\hline Cys & 0.2 & 0.9 & 3 & 6 \\
\hline Met & 1.4 & 1.7 & 10 & 11 \\
\hline Pro & 9.2 & 6.9 & 54 & 45 \\
\hline Gly & 8.1 & 10.3 & 49 & 67 \\
\hline Ala & 8.5 & 7.6 & 55 & 50 \\
\hline Val & 3.9 & 4.3 & 22 & 28 \\
\hline Leu & 7.3 & 8.1 & 46 & 53 \\
\hline Ile & 1.4 & 1.8 & 6 & 11 \\
\hline Phe & 1.7 & 1.5 & 9 & 10 \\
\hline Tyr & 1.0 & 1.1 & 6 & 7 \\
\hline Trp & 1.4 & $N^{e}$ & 7 & ND \\
\hline Lys & 8.4 & 5.3 & 54 & 35 \\
\hline His & 1.9 & 1.8 & 10 & 12 \\
\hline Arg & 6.0 & 5.6 & 41 & 36 \\
\hline
\end{tabular}

a Cohn et al. [35].

b Purified by LK2H10 affinity chromatography.

c Data from references 34 and 35.

d Based on molecular weight of 70000 .

- $\mathrm{ND}=$ not done. 


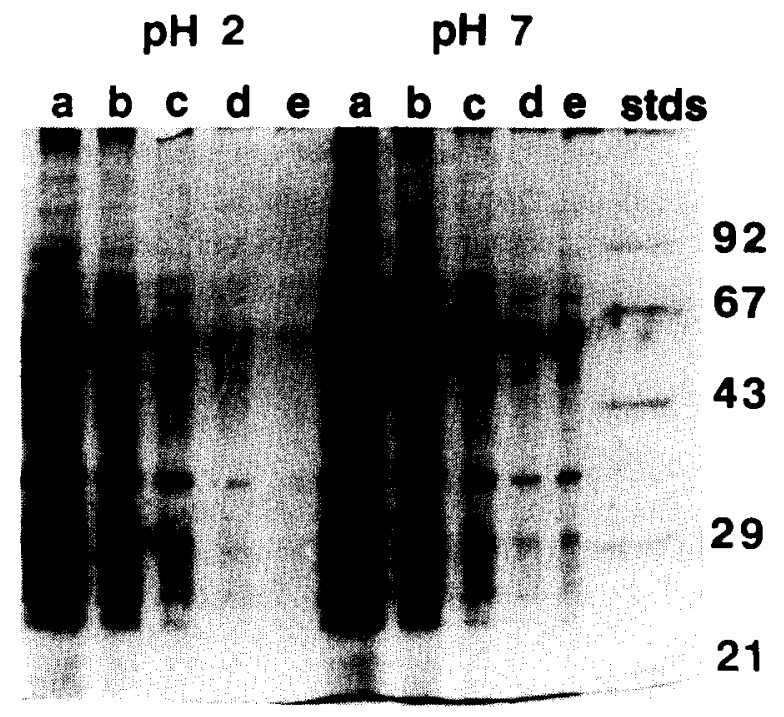

Fig. 6. SDS-PAGE and silver staining of adrenal gland extract proteins with differing pH solubilities. Adrenal extract was dried under acid conditions ( $\mathrm{pH} 2.3$ ) and those proteins solubilized by vortexing for $1 \mathrm{~min}$ and at $25^{\circ} \mathrm{C}$ using a neutral $\mathrm{pH}$ buffer were discarded. The remaining proteins were solubilized by boiling in SDS and were compared with an original untreated sample. The dilution series (a-e represent 2-fold dilutions) shows that the acid treatment affected the solubility of a portion of all proteins in the adrenal extract.

The $\mathrm{N}$-terminal amino acid sequence was defined for the first 28 residues (Fig. 7). Those residues given in parentheses are presumptive and are based on best expected yields or on comparison with the known bovine chromogranin sequence (i.e. Cys). Interestingly, a secondary sequence missing the first 3 residues of the main sequence was detected. The $1^{0}-3$ sequence represented about $25 \%$ of the total protein and was identical for all residues which could be detected. The 28 residue sequence is identical with all 20 known residues for human chromogranin A [33] and the 24 residues known for bovine chromogranin A $[11,34,35]$.

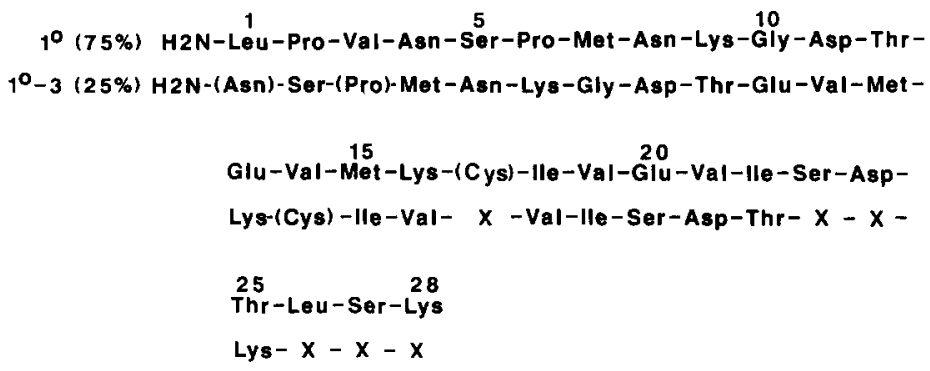

Fig. 7. N-Terminal sequence of human adrenal chromogranin. The main sequence $\left(1^{\circ}\right)$ is shown for 28 residues while the secondary sequence missing the $\mathrm{N}$-terminal first three residues $\left(1^{\circ}-3\right)$ is below. All Cys residues are in brackets since they are inferred from the lack of any other residues and are consistent with previous sequence data [32]. Other residues in brackets are the best fit based on yields. $\times$ indicates that no residue could be determined. 


\section{Discussion}

This paper presents a relatively simple method to purify significant quantities of the endocrine granule protein, chromogranin, from a readily available source of human tissue (i.e., autopsy adrenal glands). The procedure involved homogenization of tissue, salt precipitation, monoclonal antibody affinity chromatography and reverse-phase HPLC. Surprisingly, adrenal glands taken from 4-24 h post-mortem autopsies provided a stable source of chromogranin which was indistinguishable in chromogranin polypeptide complexity from chromogranin isolated from surgically excised normal adrenals and tumors. The stability of chromogranin in autopsy glands allowed us to generate about $6 \mathrm{nmol}$ of chromogranin from $97 \mathrm{~g}$ of adrenals. The adrenal medulla represents about $10 \%$ of the total adrenal gland and contains the chromaffin cells that produce chromogranin.

An interesting and unexpected finding was the difficulty encountered in suspending chromogranin in aqueous buffer following vacuum drying under acidic conditions. When drying was performed at low $\mathrm{pH}$, then chromogranin could only be efficiently suspended using either acidic or basic conditions. This phenomenon was a property of all polypeptides in the adrenal homogenate and affected serum IgG but not serum albumin. Under our experimental conditions (see Table I), we did not observe these effects when drying was performed under basic conditions $\left(\mathrm{NH}_{4} \mathrm{OH}\right)$. For this reason, we chose $\mathrm{NH}_{4} \mathrm{OH}$ to elute chromogranin from the antibody affinity column during the purification process. However, in practice, we often observed that after removal of $\mathrm{NH}_{4} \mathrm{OH}$ under vacuum, low $\mathrm{pH}$ conditions ( $2 \mathrm{~N}$ acetic acid) were also required to ensure that all the chromogram was resuspended. Unusual solubility properties have not been previously described for chromogranin, however, the use of $\mathrm{pH}$ extremes, and complete solvent removal, to our knowledge, have not been associated with previous chromogranin purification schemes.

A unique characteristic of chromogranin which should be discussed is the complex polypeptide pattern that is revealed when total chromogranins are analyzed for molecular weight in SDS gels. As seen in Fig. 3, silver staining of the fractions of the HPLC protein peak reveals a high degree of molecular weight heterogeneity from $M_{\mathbf{r}}$ 50000 to $M_{\mathrm{r}} 20000$. The fact that these polypeptides are chromogranins and not contaminant protein is revealed by the Western blot which shows that all polypeptides carry the antigenic determinant detected by our highly characterized LK2H10 monoclonal antibody $[8,10]$. The immunological identity of these polypeptides cannot be explained by spurious cross-reactivity since this complex polypeptide pattern for chromogranin has been observed previously by other investigators using conventional polyclonal antisera [7] as well as monoclonal antibodies [12]. What is important to appreciate is that the various smaller size chromogranin polypeptides are only minor components of our purified chromogranin preparation, with the majority of material represented by chromogranin polypeptide(s) exhibiting an approximate $M_{\mathrm{r}}$ 70000 . This conclusion is based on the observation that the polypeptide complexity is only readily seen when large amounts of protein are loaded onto the gels (such as from the HPLC peak fractions) and highly sensitive detection systems such as Western blotting and silver staining are used for protein detection. In fact, Coomassie 
blue staining of SDS gels shows only the main $M_{\mathrm{r}} 70000$ polypeptide and not the smaller chromogranins. In addition, silver staining of the HPLC pool (fraction 43$50)$ as seen in Fig. 4 reveals a single major cluster of polypeptides $\left(M_{\mathrm{r}} 70000\right)$ at the concentration of protein used; the smaller polypeptides were visualized only when much larger amounts of protein were analyzed. Thus, our purified chromogranin preparations contain mainly a $M_{\mathrm{r}} 70000$ polypeptide(s) which by subsequent chemical analysis (N-terminal sequence) represents chromogranin $\mathrm{A}$, and in addition contains a small amount of other chromogranin polypeptides heterogeneous in size. Chromogranin has previously been purified from bovine adrenal glands [11,12,35] and more recently from a human pheochromocytoma [36] by a process employing granule isolation and subsequent chromatographic separation of the main protein species (i.e., chromogranin A). Whether these procedures also purify the smaller or larger size chromogranin polypeptides as does our method cannot be determined unless sensitive protein detection methods along with heavily loaded gels are utilized as we have done.

An intriguing issue that remains unsettled pertains to the relationship between the various size polypeptides of the chromogranin family. Chromogranin A and some intermediate sized chromogranins are known to be glycosylated and to differ in their carbohydrate composition [6]. Whether this plays a significant role in chromogranin polypeptide heterogeneity is presently unknown. Recent $\mathrm{N}$-terminal amino acid sequence analysis of different bovine chromogranin polypeptides (i.e., $M_{\mathrm{r}} 65000$, 75000,85000 ) showed very similar yet distinct sequences, suggesting the possibility of polypeptide heterogeneity through gene duplication events [12]. In vitro translation of poly(A) mRNA isolated from endocrine tissues has been used to determine if chromogranin is synthesized as a large precursor (for proteolytic processing) or is synthesized from various sized mRNA's. Two such studies have identified a major translation product(s) which is appropriate in size as a precursor for chromogranin A $[9,13]$, while another study identified a variety of different sized chromogranin translation products [37]. Thus, it is unclear whether chromogranin structural heterogeneity occurs before or after protein translation.

Proteolytic breakdown of chromogranin A in bovine chromaffin granule lysates provided direct evidence for the possibility of chromogranin post-translational processing in situ [12]. In addition, $\mathrm{N}$-terminal processing enzymes for opioid precursors which are present in chromaffin vesicles have been suggested as potential processing enzymes for chromogranin [19]. The fact that we found $25 \%$ of our chromogranin sequence was missing the $\mathrm{N}$-terminal 3 residues would appear to be consistent with the notion of in situ proteolytic processing. However, we cannot eliminate the possibility that our secondary sequence resulted from the use of autopsy tissue as a chromogranin source. On the other hand, it should be noted that the $\beta$ chain of human chorionic gonadotropin has similarly been reported to have a secondary amino terminal sequence representing $30 \%$ of the material and missing the N-terminal 3 amino acid residues [38].

The function of chromogranin is presently unclear. The abundance of this protein in adrenal chromaffin granules led to experiments indicating a role in catecholamine storage and granule stability [14-18]. However, the present understanding of chrom- 
ogranin distribution is not consistent with that of amine distribution [11,19]. A possible breakthrough in the function of this molecule might come when the sequence of the protein is determined and is found to be homologous to other known proteins. The N-terminal 28 residues identified in this report for human chromogranin are identical at every comparable position with the 20 known residues of human [33] and the 24 known residues of bovine chromogranin $\mathrm{A}[11,34,35]$. We do note that our sequence is identical except for one residue with the sequence of bovine chromogranin A provided by Settleman et al. [12], however, recent studies of bovine chromogranin A have disputed this difference [35,36]. We compared our 28 residues with 3061 protein sequences present in the data bank of the National Biomedical Research Foundation, Washington, DC. However, no significant sequence homologies were demonstrated.

The recent human chromogranin $\mathrm{N}$-terminal 20 residue sequence by Kruggel et al. [33] together with our data extending to residue 28 shows identical homology between the bovine and human sequence at all residues which can be compared (residues 124). This was unexpected since conventional antisera to bovine or human chromogranin $\mathrm{A}$ are not usually cross-reactive [11]. In addition, our monoclonal antibody LK2H10 to human chromogranin cross-reacts only with monkey and pig adrenal tissue but not with bovine or any other species [8]. These data suggest that species divergence in the sequence has occurred at sites distal to the $\mathrm{N}$-terminus. Thus, the $\mathrm{N}$-terminal sequence of chromogranin appears to be highly conserved through evolution and as such may contain the residues most critical to the function of this molecule. Monoclonal antibodies generated against a synthetic peptide coding for the $\mathrm{N}$-terminal sequence should provide a reagent useful to detect chromogranin from all animal species.

\section{Acknowledgments}

The authors are grateful to Ms. Rachel Thayer for her excellent technical assistance and to Mr. John Lambert for his assistance in obtaining post-mortem adrenal glands. In addition, the authors acknowledge the skilled assistance of Ms. Sheila Norten of the University of Michigan Amino Acid Sequence Facility. B.S. Wilson was supported by a Public Health Career Development award from the National Cancer Institute and by Public Health Service Grant P30AM34933. Part of this work was done during the tenure of an Established Investigator award to S.H. Phan from the American Heart Association. This work was supported by NIH grants HL28737 and 31963 and by a grant-in-aid from the American Heart Association with funds from its Michigan Affiliate.

\section{References}

1 Banks, P. and Helle, K., The release of protein from the stimulated adrenal medulla, Biochem. J., 97 (1965) 40-41C.

2 Kirshner, N., Sage, H.J., Smith, W.J. and Kirshner, A.G., Release of catecholamines and specific protein from adrenal glands, Science, 154 (1966) 529-531. 
3 Schneider, F. H., Smith, A.D. and Winkler, H., Secretion from the adrenal medulla: biochemical evidence for exocytosis, Br. J. Pharmacol. Chemother., 31 (1967) 94-104.

4 Blaschko, H., Comline, R.S., Schneider, F.H., Silver, M. and Smith, A.D., Secretion of a chromaffin granule protein, chromogranin, from the adrenal gland after splanchnic stimulation, Nature, 215 (1967) 58-59.

5 Winkler, H. and Carmichael, S.W., The chromaffin granule. In A.M. Poisner and J.M. Trifaro (Eds.), The Secretory Granule, Elsevier Biomedical Press, Amsterdam, 1982, pp. 3-79.

6 Kiang, W.-L., Krusius, T., Finne, J., Margolis, R.U. and Margolis, R.U., Glycoprotein and proteoglycans of the chromaffin granule matrix, J. Biol. Chem., 257 (1982) 1651-1659.

7 Hortnagl, H., Lochs, H. and Winkler, H., Immunological studies on the acidic chromogranins and on dopamine $\beta$-hydroxylase (EC 1.14.2.1) of bovine chromaffin granules, J. Neurochem., 22 (1974) 197-199.

8 Lloyd, R.V. and Wilson, B.S., Specific endocrine tissue marker defined by a monoclonal antibody, Science, 222 (1983) 628-630.

9 Kilpatrick, L., Gavine, F., Apps, D. and Phillips, J., Biosynthetic relationship between the major matrix proteins of the adrenal chromaffin granules, FEBS Lett., 164 (1983) 383-388.

10 Wilson, B.S. and Lloyd, R.V., Detection of chromogranin in neuroendocrine cells with a monoclonal antibody, Am. J. Pathol., 115 (1984) 458-468.

11 O'Connor, D.T. and Frigon, R.P., Chromogranin A, the major catecholamine storage vesicle soluble protein, J. Biol. Chem., 259 (1984) 3237-3247.

12 Settleman, T., Fonseca, R., Nolan, J. and Angeletti, R.H., Relationship of multiple forms of chromogranin, J. Biol. Chem., 260 (1985) 1645-1651.

13 Falkensammer, A., Fischer-Colbrie, R., Richter, K. and Winkler, H., Cell-free and cellular synthesis of chromogranin A and B of bovine adrenal medulla, Neuroscience, 14 (1985) 735-746.

14 Blaschko, H. and Helle, K.B., Interaction of soluble protein fractions from bovine adrenal medullary granules with adrenaline and adenosinetriphosphate, J. Physiol. (Lond.), 169 (1963) 120-121P.

15 Smith, W.J. and Kirshner, N., A specific soluble protein from the catecholamine storage vesicles of bovine adrenal medulla. Purification and chemical characterization, Mol. Pharmacol, 3 (1967) 52-62.

16 Berneis, K.H., Goetz, U., DePrada, M. and Pletscher, A., Interaction of aggregated catecholamines and nucleotides with intragranular proteins, Naunyn-Schmiedeberg's Arch. Pharmacol., 277 (1973) 291-296.

17 Sharp, R.R. and Richards, E.P., Molecular mobilities of soluble components in the aqueous phase of chromaffin granules, Biochim. Biophys. Acta, 497 (1977) 260-271.

18 Uvnäs, B. and Aborg, C.-H., In vitro studies on a two pool storage of adrenaline and noradrenaline in granule material from bovine adrenal medulla, Acta Physiol. Scand., 109 (1980) 345-354.

19 Somogyi, P., Hodgson, A.J., DePotter, R.W., Fischer-Colbrie, R., Schober, M., Winkler, H. and Chubb, I.W., Chromogranin immunoreactivity in the central nervous system. Immunochemical characterization, distribution and relationship to catecholamine and enkephalin pathways, Brain Res., 8 (1984) 193-230.

20 O'Connor, D.T., Burton, D. and Deftos, L.J., Chromogranin A: Immunohistology reveals its universal occurrence in normal polypeptide hormone producing endocrine glands, Life Sci., 33 (1983) 16571663.

21 O'Connor, D.T., Burton, D. and Deftos, L.J., Immunoreactive human chromogranin A in diverse polypeptide hormone producing human tumors and normal endocrine tissues, J. Clin. Endocrinol. Metab., 57 (1983) 1084-1086.

22 Cohn, D.V., Elting, J.J., Frick, M. and Elde, R., Selective localization of the parathyroid secretory protein I adrenal medulla chromogranin A protein family in a wide variety of endocrine cells of the rat, Endocrinology, 114 (1984) 1963-1974.

23 O'Connor, D.T., Chromogranin: widespread immunoreactivity in polypeptide hormone producing tissues and in serum, Regul. Peptides, 6 (1983) 263-280.

24 DeStephano, D.B., Lloyd, R.V., Pike, A.M. and Wilson, B.S., Pituitary adenomas: An immunohistochemical study of hormone production and chromogranin localization, Am. J. Pathol., 116 (1984) 464-472.

25 Lloyd, R.V., Mervak, T., Schmidt, K., Warner, T. and Wilson, B.S., Immunohistochemical detection 
of chromogranin and neuron-specific enolase in pancreatic endocrine neoplasms, Surg. Pathol., 8 (1984) 607-614.

26 Pearse, A.G.E., The diffuse neuroendocrine system and the APUD concept: Related endocrine peptides in brain, intestine, pituitary, placenta, and anuran cutaneous glands, Med. Biol., 55 (1977) 115-125.

27 Fahey, J., Chromatographic separation of immunoglobulins. In Williams, C.A. and Chase, M.W. (Eds.), Methods in Immunology and Immunochemistry, Academic Press, NY, 1967, 1, 322.

28 Peters, J. and Coon, A., Fluorescent antibody or specific cytochemical agents. In Williams, C.A. and Chase, M.W. (Eds.), Methods in Immunology and Immunochemistry, Academic Press, NY, 1976, 5, 424-444.

29 Laemmli, U.K., Cleavage of structural proteins during assembly of the head of bacteriophage T4, Nature, 222 (1970) 680-685.

30 Towbin, H., Staehelin, T. and Gordon, J., Electrophoretic transfer of proteins from polyacrylamide gels to nitrocellulose sheets: Procedures and some applications, Proc. Natl. Acad. Sci. USA, 76 (1979) 4350-4354.

31 Cuatrecasas, P., Protein purification by affinity chromatography. Derivativations of agarose and polyacrylamide beads, J. Biol. Chem., 245 (1970) 3059-3065.

32 Hewick, R.M., A gas-liquid solid phase peptide and protein sequenator, J. Biol. Chem., 256 (1981) 7990-7997.

33 Kruggel, W., O'Connor, D.T. and Lewis, R.V., The amino terminal sequences of bovine and human chromogranin A and secretory protein I are identical, Biochem. Biophys. Res. Commun., 127 (1985) 380-383.

34 Smith, A.D. and Winkler, H., Purification and properties of an acidic protein from chromaffin granules of the bovine adrenal medulla, Biochem. J., 103 (1967) 483-492.

35 Cohn, D.V., Zangerle, R., Fischer-Colbrie, R., Chu, L.L.H., Elting, J.J., Hamilton, J.W. and Winkler, H., Similarity of secretory protein I from parathyroid gland to chromogranin A from adrenal medulla, Proc. Natl. Acad. Sci. USA, 79 (1982) 6056-6059.

36 O'Connor, D.T., Frigon, R.P. and Sokoloff, R.L., Human chromogranin A: Purification and characterization from catecholamine storage vesicles of human pheochromocytoma, Hypertension, 6 (1984) 2-12.

37 Serck-Hanssen, G.S. and O'Connor, D.T., Immunological identification and characterization of chromogranin coded by poly(A) mRNA from bovine adrenal medulla and pituitary and human phaeochromocytoma, J. Biol. Chem., 259 (1984) 11597-11600.

38 Morgan, F.J., Birken, S. and Canfield, R.E., Human chorionic gonadotropin: A proposal for the amino acid sequence, Mol. Cell. Biochem., 2 (1973) 97-99. 